\title{
SOEP
}

SOEPpapers

SOEPpapers
on Multidisciplinary Panel Data Research
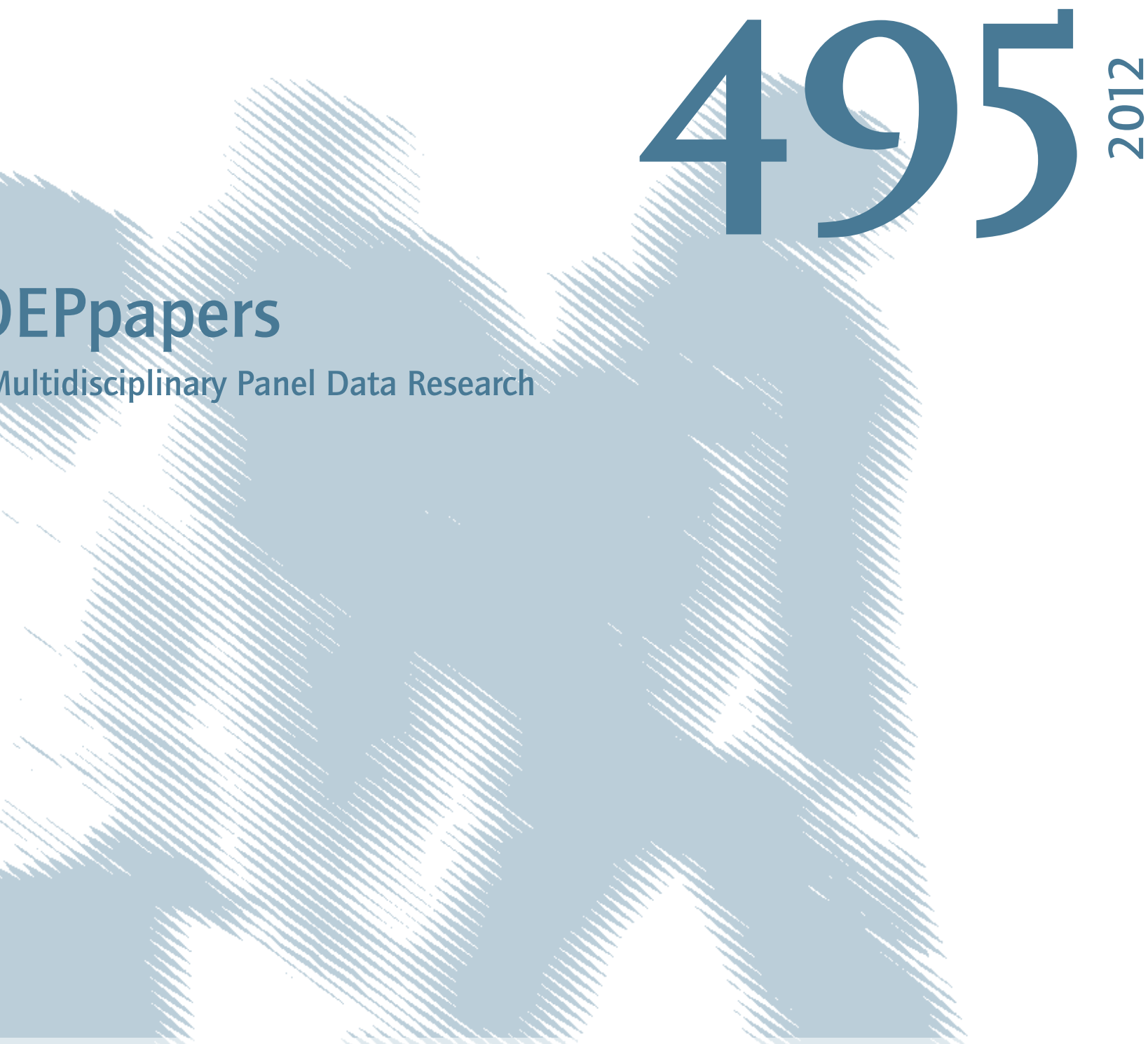

\section{Internal migration of ethnic minorities - Evidence from Western Germany}




\section{SOEPpapers on Multidisciplinary Panel Data Research}

at DIW Berlin

This series presents research findings based either directly on data from the German SocioEconomic Panel Study (SOEP) or using SOEP data as part of an internationally comparable data set (e.g. CNEF, ECHP, LIS, LWS, CHER/PACO). SOEP is a truly multidisciplinary household panel study covering a wide range of social and behavioral sciences: economics, sociology, psychology, survey methodology, econometrics and applied statistics, educational science, political science, public health, behavioral genetics, demography, geography, and sport science.

The decision to publish a submission in SOEPpapers is made by a board of editors chosen by the DIW Berlin to represent the wide range of disciplines covered by SOEP. There is no external referee process and papers are either accepted or rejected without revision. Papers appear in this series as works in progress and may also appear elsewhere. They often represent preliminary studies and are circulated to encourage discussion. Citation of such a paper should account for its provisional character. A revised version may be requested from the author directly.

Any opinions expressed in this series are those of the author(s) and not those of DIW Berlin. Research disseminated by DIW Berlin may include views on public policy issues, but the institute itself takes no institutional policy positions.

The SOEPpapers are available at

http://www.diw.de/soeppapers

\section{Editors:}

Jürgen Schupp (Sociology, Vice Dean DIW Graduate Center)

Gert G. Wagner (Social Sciences)

Conchita D'Ambrosio (Public Economics)

Denis Gerstorf (Psychology, DIW Research Director)

Elke Holst (Gender Studies, DIW Research Director)

Frauke Kreuter (Survey Methodology, DIW Research Professor)

Martin Kroh (Political Science and Survey Methodology)

Frieder R. Lang (Psychology, DIW Research Professor)

Henning Lohmann (Sociology, DIW Research Professor)

Jörg-Peter Schräpler (Survey Methodology, DIW Research Professor)

Thomas Siedler (Empirical Economics)

C. Katharina Spieß (Empirical Economics and Educational Science)

ISSN: 1864-6689 (online)

German Socio-Economic Panel Study (SOEP)

DIW Berlin

Mohrenstrasse 58

10117 Berlin, Germany

Contact: Uta Rahmann | soeppapers@diw.de 


\title{
Internal migration of ethnic minorities - Evidence from Western Germany
}

\author{
Belit Şaka1 \\ University of Duisburg-Essen \\ Institut of Sociology \\ Lotharstr. 65 \\ 47057 Duisburg
}

Tel: +49-203-379 2744

E-mail: belit.saka@uni-due.de

\begin{abstract}
This paper deals with long distance internal migration patterns of the immigrant population in Germany and addresses the question whether immigrants are more mobile than native Germans and to what extent the differences in spatial mobility behavior between immigrants and native Germans are influenced by a) individual level characteristics, b) macro level regional economic characteristics and c) regional ties. The analysis shows in general a very low rate of long distance internal migration in Germany for native Germans as well as for immigrants. Even after controlling for individual and regional level characteristics, the immigrant population is half as mobile as native Germans. The results are more robust for the $2^{\text {nd }}$ generation immigrants.
\end{abstract}

\footnotetext{
${ }^{1}$ I would like to thank Sergi Vidal Torre, Michael Windzio, Marco Giesselmann, Marcel Erlinghagen and Christiane Lübke for helpful comments, Jan Goebel for almost round-the-clock support with SOEPremote and Friedrich Scheller for providing me the data on county level nativity concentration of foreign population in Germany.
} 


\section{Introduction}

Internal migration is a selective process which is affected by individual as well as by regional characteristics. There is a rich selection of studies which approach internal migration with its patterns, determinants and consequences from different perspectives. Issues of particular interest are the migration process embedded in the life course perspective (Kley, 2009; 2010; Huinink / Kley, 2008; Kalter, 1997; Wagner, 1989), the association of migration with regional labor market characteristics (Windzio, 2004a; 2004b; Mertens / Haas, 2006; Arntz, 2005), migration in the context of family (Jürges, 2005; 1998) and the relation of geographic mobility with social ties (Vidal Torre / Kley, 2010; Vidal Torre, 2009) as well as with regional ties or regional identities (Kley, 2008; Abraham / Nisic, 2007). Also the internal migration of ethnic minorities in a host country has been well documented (Ellis / Goodwin-White, 2006; Finney / Simpson, 2008; Foulkes / Newbold, 2000; Gurak / Kritz, 2000; Kritz / Nogle, 1994; Newbold, 1999; Spilembergo / Úbeda, 2004; Kulu / Billiari, 2004; 2006). Research in this latter field, however, comes mainly from Anglo-American literature and little is known about internal migration of ethnic minorities in Germany apart from a few exceptions (Schündeln 2007). The long-term impact of internal migration on the demographic as well as the socioeconomic development in both sending and receiving region is well known (Mai / Scharein, 2009). Keeping in mind, that there are 15.4 million people with migration background living in Germany which will, according to population prognoses, constitute one third of the whole population in 2050 (Statistisches Bundesamt 2009), internal migration patterns of ethnic minorities will become both socially and politically more relevant. Against this background, this study poses the question, whether and how immigrants in Germany differ from native Germans concerning internal migration patterns. And to what extent differences in internal migration behaviors are generated by individual level characteristics, by macro level regional economic characteristics and by regional social ties. The analysis is based on ten waves from the German Socio-economic Panel (GSOEP) covering the years 2000 until 2009. 
The paper is structured as follows: The next sections outlines the theoretical arguments supported with empirical findings, mostly from Anglo-American research, on internal migration of ethnic minorities specifying some expectations. Section 3 contains the description of data and variables. Empirical findings are presented in section 4 . The last section discusses the major findings concluding with an outlook for future research.

\section{Literature review and theoretical background}

Migration can be considered as a multilevel process. This chapter shortly outlines the determinants of migration based on this underlying multilevel perspective, divided into a) micro level individual characteristics, b) macro level regional economic characteristics and c) meso level regional social ties, and how these can contribute to explain the migration propensities of ethnic minorities in Germany. To avoid confusion, migration is defined as a long-distance move within a country which not only includes the change of residence but also the change of the location of other daily activities like workplace, school, shopping as well as leisure activities (Jürges, 1998). In this sense, migration is considered synonymous with internal migration and (long-distance spatial) mobility.

To start with the micro level, migration is affected by individual characteristics and resources such as age, education level, marital status, employment status, sex, number of children in the household, ethnic background, migration experience etc. According to the human capital perspective, migration has been considered as an investment into human capital. Before taking the migration decision, individuals calculate both short and long term material and immaterial costs and benefits of migration and translate it into action only if the expected benefits of migration exceed its costs (Sjaastad, 1962). The economic advantages of a migration would be e.g. greater for younger people and for the ones who invested more in education as it is also indicated in the empirical research (Newbold, 1999; Kulu / Billiari, 2006; Jürges, 1998; Windzio, 2004a). Since individual level characteristics could differ by different nativity groups (Kritz 
/ Nogle, 1994), it can be hypothesized that the nativity group composition could partly explain the differences in migration propensity between native Germans and immigrant groups. This means, that the higher mobility rates of some immigrant groups could be explained by the in-group composition which e.g. consists of younger people in average. To summarize, the individual level characteristics are to test in order to find out whether they do account for differences between natives and immigrants.

Even though individual level determinants possess great explanatory power, it is doubtful whether they could cover up a great portion of the intergroup differences in migration propensities as it is also shown in the U.S. American research on interstate migration of immigrants (Kritz / Nogle, 1994; Gurak / Kritz, 2000; Spilembergo / Úbeda, 2004). At the macro level, the economic condition of the region also could shape the migration decisions of individuals. So far, there has been research of the effect of unemployment rates, employment growth, average per capita income and labor force composition (Kritz / Nogle, 1994; Gurak / Kritz, 2000; Windzio, 2004a). Economically argued, migration follows the direction of rising wages and shrinking unemployment. In this sense, regions where the average per capita income is low and the unemployment rate is high would account as sending regions. Some empirical findings also support this theoretical argumentation (Hunt, 2006). However, the neoclassical economic theory applied to immigrant groups reveals a different picture. Exploring internal migration patterns of different immigrant groups in the USA, Kritz / Nogle (1994) found out different levels and directions of the effect of regional unemployment rate depending on nationality group. Therefore, in light of the contradictory empirical evidence, controlling regional unemployment I expect to find out the degree of attachment of immigrant groups to the economic structure of the region.

In addition to the macro and micro level economic theories, Faist (1997) emphasized the importance of the "crucial meso-level" as a link between individual cost and benefit calculations and the structural macro level. Accordingly, migration decisions are not only economically motivated but also framed by social relations and social capital in regions, neighborhoods or communities. Social capital can be de- 
scribed as resources of persons at the individual level (such as proximity to friends and family, community affiliation) but also on an upper level as a resource of a given (nativity) group (Haug 2000). At the individual level, drawing on the cumulative inertia theorem from McGinnis (1968) it can be assumed that with increasing duration of stay in one region the migration rate decreases. The time spent in one region can be translated into greater social integration into that region, which could lead to a lower likelihood to leave the region. In addition to duration of stay also homeownership indicates a strong regional attachment for the natives as well as for immigrant groups. Keeping in mind that immigrants mostly first settle in regions and communities where their co-nationals already reside in order to benefit from the advantages of the existing immigrant networks (Heckmann, 1992; Friedrichs, 2008), the nativity concentration of the region can also be considered as a proxy of existing social capital in that region as it is mostly done in U.S. American research. Proximity to co-nationals - measured as state level ethnic concentration in the US - in fact has been observed as a migration deterrent factor (Kritz / Nogle, 1994; Gurak / Kritz, 2000; Foulkes / Newbold, 2000; Newbold, 1999; Ellis / Goodwin-White, 2006). But, reducing social capital to a constant determinant for all members of a given nativity group is based on the assumptions that the networks of co-nationals are homogenous and the network effects are unidirectional. It can therefore only provide a rough estimate and should be interpreted with caution.

\section{Data sources and variables}

The empirical analysis is based on data from German Socio-Economic Panel (GSOEP). GSOEP is a representative household and individual level panel study which includes a broad spectrum of topics like demography, labor market, economic situation, health, education, value orientation, integration as well as housing (Wagner et al., 2007). GSOEP is a suitable dataset for the research question because of its longitudinal character as for capturing internal migration information from at least two consecutive waves is needed. Moreover, the dataset provides - due to the overrepresentation of the population with 
migration background - sufficient number of cases of minority populations (Frick, 2006). The data has been linked to the regional information from German Federal Institute for Research on Building, Urban Affairs and Spatial Development using the NUTS Geocodes standards at the NUTS- $3^{2}$ level based on small-scale official district codes $^{3}$. As the exact distance between two following residences was only available from the wave 2000 upwards which represents the key information of the study, the analysis covers an observation period of ten waves between 2000 and 2009 (Goebel, 2011). To focus on migration patterns of working age population, the dataset consists of heads of households aged 16 to 65 , not having entered the retirement period yet. Population with migration background consists of immigrants from former guest worker countries ${ }^{4}$ and their descendants as these are the biggest immigrant groups in Germany and can partly be treated as a distinct group due to their similar migration history. Even though, it would have been better analyzing each group separately, it was not possible because of the restricted number of cases. As these nations have been recruited during recruitment period (1955-1973) from Western Germany where they also mostly settled down, Eastern Germany has been excluded from the analysis (Bade / Oltmer, 2003).

The dichotomous dependent variable gives information about, whether a person has changed his/her residence from one county to another covering more than $50 \mathrm{~km}$ of distance in two consecutive waves. This information is based on the question in the household questionnaire "Did you live in this flat the last time we interviewed you about a year ago?". In light of the former research on internal migration (Jürges, 2005), residential moving definition is extended to interregional migration based on the information from regional data about moving distance (over $50 \mathrm{~km}$ ) and changing the county.

Individual variables: People with migration background are identified combining parental information with individual data based on all available waves from 1984 to 2009, which can be summarized as fol-

\footnotetext{
${ }^{2}$ NUTS-3 corresponds in Germany counties - (Land-)Kreise and kreisfreie Städte

${ }^{3}$ The access to kreise file underlies strict conditions and requires a special user contract. The analyses are run via email using SOEPremote execution system.

${ }^{4}$ Turkey, Italy, Spain, Portugal, Greece, former Yugoslavian Republics
} 
lows: (1) born in a foreign country and/or, (2) not in possession of the German nationality and/or, (3) the parents were not born in Germany and/or do not possess the German nationality. In addition, it was possible to distinguish between different nationality groups. In a second step, individuals with migration background are differentiated into the first and second generation ${ }^{5}$. Furthermore, I control for respondent's age, sex, education level, marital status, number of children in the household and occupational status. Finally, indicators such as home ownership and duration of residence are integrated into the models as proxies for regional attachment and cumulative-inertia.

Macro level variables: Economic condition in the region is captured by the unemployment rate which was available in the regional dataset from GSOEP (kreise). Information on the nativity concentration in the region is collected from several federal statistical offices. In addition, I included four dummy variables measuring the urbanization degree of the region, based on the data and definition of the BBR (INKAR 2011). For descriptive characteristics of the variables used in the analysis and further information about their operationalization are summarized in the appendix A1 and A2.

\section{Empirical findings}

Table 1 presents first descriptive information on the internal migration rate of individuals with guest worker migration background and native Germans in Western Germany. First of all, the analysis underlines a substantial variation in the migration rate between the two groups. Internal migration rate of individuals with guest worker background $(0.67 \%)$ is almost half of native Germans (1.13\%). Apart from that, it has also to be mentioned that migration with a distance above $50 \mathrm{~km}$ is a very seldom observed phenomenon in the dataset which is also demonstrated in the absolute number of cases.

\footnotetext{
${ }^{5} 1^{\text {st }}$ generation: born in a foreign country and immigrated to Germany after the age of six; $2^{\text {nd }}$ generation: born in Germany or immigrated before having reached the age of six.
} 
Table 1

\section{Migration rate of individuals with migration background and German-born natives}

\begin{tabular}{lccc}
\hline Nationality background & $\mathbf{N}$ & \multicolumn{2}{c}{ internal migration } \\
& & $\mathbf{5 0 \mathbf { k m } )}$ & $\mathrm{n}$ \\
\hline native Germans & 77,986 & 1.13 & 880 \\
guest worker background & 11,069 & 0.67 & 74 \\
\hline Total & 89,055 & 1.07 & 954 \\
\hline \multicolumn{1}{c}{ Source: GSOEP 2000-2009 pooled dataset. }
\end{tabular}

However, the question is to what extend differences in probability of internal migration between individuals with guest worker background and native Germans can be explained by different individual and contextual characteristics. As this paper is the first attempt to describe and explain the internal migration phenomenon of ethnic minorities, simple logistic regression models has been used for the dichotomous dependent variable of internal migration. Furthermore, the models are clustered by individuals in order to take into account the panel structure of the data (Giesselmann / Windzio, 2012). The results are presented in Table 2. I used stepwise modeling techniques to disentangle the mediating effects of different determinants. Therefore, additionally to odds ratios (OR), $y$-standardized beta coefficients (BStdY) are presented as the latter coefficient allows a comparison across the nested models ${ }^{6}$ (Mood, 2010).

To begin with, the first model only includes the ethnic origin differentiated by generational status. The results indicate that the $1^{\text {st }}$ generation immigrants from former guest worker countries are less likely than the $2^{\text {nd }}$ generation immigrants and native Germans to move within Germany more than $50 \mathrm{~km}$. Age, marital status married and presence of children are - in line with the theory - negatively associated with migration and partly account for explaining the difference between $1^{\text {st }}$ generation immigrants and Germans in the second model. But interestingly, the non-significant effect from model 1 for the $2^{\text {nd }}$ generation immigrants becomes after introducing social demographic characteristics at once significant.

\footnotetext{
${ }^{6}$ However, in contrast to the intensive discourse about logistic regression, in this specific case it does not make any difference whether one compares the increasing and decreasing in odds ratios or in standardized beta coefficients across succeeding models.
} 
Whereas the differences to the $1^{\text {st }}$ generation disappear after controlling for educational level and employment status in model 3 , striking differences to the $2^{\text {nd }}$ generation immigrants still remain.

In model 4, the determinants of individual's regional embeddedness are included. As expected, homeownership is negatively associated with internal migration and with increasing duration of housing the propensity of migration decreases. But surprisingly, including occupancy in the model the distance between Germans and immigrants raises. Even the odds for the $1^{\text {st }}$ generation become at once significant. Interaction effects between migration background and occupancy have shown ${ }^{7}$, that cumulative inertia phenomenon can only be applied to native Germans and does not account for immigrant subpopulation in the GSOEP. The longer immigrants live in a housing it is more likely that they are to make an interregional move.

Model 5 includes regional unemployment rate and model 6 nativity concentration of each group as a macro level indicator of social capital as it has been applied in Anglo-American literature. Unemployment rate does not possess any effect on internal migration whereas nativity concentration fosters migration. But none of them could make a formidable contribution neither to increasing or decreasing the coefficients for migration background variables nor to the model fit. Detailed analysis introducing interaction terms ${ }^{8}$ with context level indicators and migration background have shown that the significant positive effect of nativity concentration only accounts for Germans. On the other hand, the effects of nativity concentration for the $1^{\text {st }}$ and $2^{\text {nd }}$ generation immigrants show the opposite direction which could be interpreted as a sign that social capital acts as a migration deterrent factor for immigrants. However, the coefficients stayed below the conventional level of significance. Besides, regional level unemployment rate does not have any effect on none of the groups.

\footnotetext{
${ }^{7}$ Models are not shown.

${ }^{8}$ Models are not shown and available on demand.
} 
Table 2

\section{Logistic regression models of internal migration ( $>50 \mathrm{~km})$ on individual and contextual level determinants}

\begin{tabular}{|c|c|c|c|c|c|c|c|c|c|c|c|c|}
\hline & \multicolumn{2}{|c|}{$\begin{array}{l}\text { Model } 1 \\
\text { Migr. Background }\end{array}$} & \multicolumn{2}{|c|}{$\begin{array}{l}\text { Model } 2 \\
\text { Socio-demorg. }\end{array}$} & \multicolumn{2}{|c|}{$\begin{array}{c}\text { Model } 3 \\
\text { Socio-econ. }\end{array}$} & \multicolumn{2}{|c|}{$\begin{array}{l}\text { Model } 4 \\
\text { regional embedd. }\end{array}$} & \multicolumn{2}{|c|}{$\begin{array}{c}\text { Model } 5 \\
\text { Context: unempl. }\end{array}$} & \multicolumn{2}{|c|}{$\begin{array}{c}\text { Model } 6 \\
\text { Context: nat. con. }\end{array}$} \\
\hline & OR & BStdY & OR & BStdY & OR & BStdY & OR & BStdY & OR & BStdY & OR & BStdY \\
\hline \multicolumn{13}{|l|}{ Individual factors } \\
\hline \multicolumn{13}{|l|}{ Migration background } \\
\hline 1st gen. (Ref: German) & $0.30 * * *$ & -0.65 & $0.51 *$ & -0.37 & 0.68 & -0.21 & $0.55 *$ & -0.31 & 0.57 & -0.29 & $0.53 *$ & -0.33 \\
\hline 2nd gen. (Ref: German) & 0.94 & -0.04 & $0.52 *$ & -0.36 & $0.57 *$ & -0.30 & $0.56 *$ & -0.30 & $0.58 *$ & -0.28 & $0.54 *$ & -0.32 \\
\hline \multicolumn{13}{|l|}{ Socio-demographics } \\
\hline age & & & $0.92 * * *$ & -0.05 & $0.92 * * *$ & -0.04 & $0.95 * * *$ & -0.03 & $0.95 * * *$ & -0.03 & $0.95 * * *$ & -0.03 \\
\hline sex (female=1) & & & 0.99 & -0.01 & 0.95 & -0.03 & 0.94 & -0.03 & 0.94 & -0.03 & 0.94 & -0.03 \\
\hline married & & & $0.49 * * *$ & -0.39 & $0.50 * * *$ & -0.37 & $0.69 * *$ & -0.19 & $0.68 * *$ & -0.20 & $0.68 * *$ & -0.20 \\
\hline children in household & & & $0.48 * * *$ & -0.40 & $0.53 * * *$ & -0.34 & $0.58 * * *$ & -0.29 & $0.58 * * *$ & -0.28 & $0.58 * * *$ & -0.28 \\
\hline \multicolumn{13}{|c|}{ Education level (Ref: without adequate degree) } \\
\hline general/basic vocational & & & & & 0.65 & -0.23 & 0.66 & -0.22 & 0.65 & -0.22 & 0.67 & -0.21 \\
\hline intermadiate & & & & & 1.10 & 0.05 & 1.17 & 0.08 & 1.19 & 0.09 & 1.21 & 0.10 \\
\hline maturity certificate & & & & & 1.55 & 0.24 & 1.65 & 0.26 & 1.76 & 0.29 & 1.80 & 0.30 \\
\hline tertiary education & & & & & $2.26 * * *$ & 0.44 & $2.79 * *$ & 0.54 & $2.95 * *$ & 0.56 & $3.07 * *$ & 0.58 \\
\hline \multicolumn{13}{|c|}{ Employment status (Ref: employed) } \\
\hline in education & & & & & $1.83 * * *$ & 0.32 & $1.84 * * *$ & 0.32 & $1.87 * * *$ & 0.32 & $1.85 * * *$ & 0.32 \\
\hline unemployed & & & & & $2.38 * * *$ & 0.47 & $2.09 * * *$ & 0.39 & $2.12 * * *$ & 0.39 & $2.07 * * *$ & 0.38 \\
\hline not working & & & & & $2.04 * *$ & 0.38 & $2.04 * *$ & 0.37 & $2.03 * *$ & 0.37 & $2.03 * *$ & 0.37 \\
\hline sellf employed & & & & & 1.00 & 0.00 & 1.02 & 0.01 & 1.02 & 0.01 & 1.02 & 0.01 \\
\hline \multicolumn{13}{|l|}{ Regional embeddedness } \\
\hline occupancy (log) & & & & & & & $0.80 * * *$ & -0.12 & $0.81 * * *$ & -0.11 & $0.81 * *$ & -0.11 \\
\hline homeownership & & & & & & & $0.32 * * *$ & -0.59 & $0.31 * * *$ & -0.61 & $0.31 * * *$ & -0.61 \\
\hline \multicolumn{13}{|l|}{ Contextual determinants } \\
\hline \multirow{2}{*}{\multicolumn{5}{|c|}{$\begin{array}{l}\text { unemployment rate (grand mean centered) } \\
\text { nativity concentration (z-tranformed) }\end{array}$}} & & & & & 0.99 & 0.00 & & \\
\hline & & & & & & & & & & & $1.10 * * *$ & 0.05 \\
\hline$N$ & \multicolumn{2}{|l|}{44952} & \multicolumn{2}{|c|}{44952} & \multicolumn{2}{|c|}{44952} & \multicolumn{2}{|c|}{44952} & \multicolumn{2}{|l|}{44952} & \multicolumn{2}{|c|}{44952} \\
\hline Pseudo $\mathrm{R}^{2}$ & \multicolumn{2}{|l|}{0.01} & \multicolumn{2}{|c|}{0.11} & \multicolumn{2}{|c|}{0.13} & \multicolumn{2}{|l|}{0.15} & \multicolumn{2}{|l|}{0.15} & \multicolumn{2}{|c|}{0.15} \\
\hline Log likelihood & \multicolumn{2}{|l|}{-2891.05} & \multicolumn{2}{|c|}{-2588.21} & -2516. & & -2475.2 & & -2470.6 & & -2469. & 43 \\
\hline
\end{tabular}

Note: Models 5 and 6 additionally control for urbanization degree, results not shown on the table. The models are clustered by personal ID number, robust standard errors of the estimates not shown.

Significance level: $* * * p<0.001 ; * * p<0.01 ; * p<0.05$

Source: GSOEP 2000-2009, own calculations.

In order to conclude, the core findings of the analysis can be summarized as follows: In general, internal migration is a remarkable seldom observed phenomenon in the dataset and individuals with guest worker background are almost half as mobile as native Germans. Differentiating into generational status, the difference between $2^{\text {nd }}$ generation immigrants with guest worker background and native Germans is quite robust and does not change after controlling for individual and regional characteristics. However, the same statement cannot be concluded for the $1^{\text {st }}$ generation so easily. Even though the general tendency is the same, the estimates are not as robust as for the $2^{\text {nd }}$ generation as the level of significance 
and the effect size oscillate across models. This can also be interpreted as a hint that some independent variables might be interrelated.

\section{Discussion and conclusion}

This paper was a first attempt to disentangle the internal migration phenomenon of ethnic minorities in Germany and addressed the question whether there are any differences between native Germans and individuals with guest worker background concerning internal migration propensities, and how these differences might be influenced by individual level characteristics, bonds to the region and regional level economic conditions. The core finding is that guest worker origin immigrants, the $1^{\text {st }}$ as well as the $2^{\text {nd }}$ generation, in Germany are less mobile than native Germans, whereas the results for the $2^{\text {nd }}$ generation are more robust then for the $1^{\text {st }}$ generation.

But in the end, several questions arise from these results: Why are immigrants from former guest worker countries, especially from $2^{\text {nd }}$ generation, significantly less mobile compared to native Germans, even after having controlled for individual and regional characteristics? Is this due to cultural differences? Are $2^{\text {nd }}$ generation immigrants more obliged to give family care which makes them immobile? Are strong family ties for immigrants more important than weak ties in a given region? Is rather a different measure of social capital needed? Or is the very low internal migration rate of immigrants in fact caused by drop outs from the survey as they returned to the country of origin? To conclude, at the end there are more questions left than answers. Therefore, these results are to be seen as first assigns for further research in this field. 


\section{References}

Abraham, M. / Nisic, N. (2007): Regionale Bindung, räumliche Mobilität und Arbeitsmarkt - Analysen für die Schweiz und Deutschland, Schweizerische Zeitschrift für Soziologie, 33 (1), 69 - 87

Arntz, M. (2005): The geographical mobility of unemployed workers. Evidence from West Germany, ZEW Discussion Paper No. 05-34, Mannheim.

Bade, K. / Oltmer, J. (2003): Zwischen Aus- und Einwanderungsland: Deutschland und die Migration seit der Mitte des 17. Jahrhunderts, Zeitschrift für Bevölkerungswissenschaft 2-4, 263-306.

Ellis, M. / Goodwin-White, J. (2006): 1.5 Generation Internal Migration in the U.S.: Dispersion from the States of Immigration?, International Migration Review 40, 899-926.

Faist, T. (1997): The Crucial Meso-Level, In: T. Hammar / G. Brochmann / K. Tamas / T. Faist (eds.), International Migration, Immobility and Development, Oxford, 187-217.

Finney, N. / Simpson, L. (2008): Internal Migration and Ethnic Groups: Evidence for Britain from the 2001 Census, Population, Space and Place 14, 63-83.

Foulkes, M. / Newbold, K. B. (2000): Migration Propensities, Patterns, and the Role of Human Capital: Comparing Mexican, Cuban and Puerto Rican Interstate Migration, 1985-1990, Professional Geographer 52, 133-145.

Frick, J. R. (2006): A General Introduction to the German Socio-Economic Panel Study (SOEP) - Design, Contents and Data Structure [waves A-V, 1984-2005]. Retrieved from: http://www.diw.de/documents/dokumentenarchiv/17/43529/soep_overview.pdf

Friedrichs, J. (2008): Ethnische Segregation. In: F. Kalter (eds.), Migration und Integration, Wiesbaden, 380-411.

Giesselmann, M / Windzio, M. (2012): Regressionsmodelle zur Analyse von Paneldaten, Wiesbaden.

Goebel, J. (2011): Informationen zur SOEP-Geocode CD. Raumordnungsregionsnummern seit 1985 und Regionalindikatoren für Raumordnungsregionen der alten Bundesländer 1984-1994. Retrieved from: http://www.diw.de/documents/dokumentenarchiv/17/74806/ror_dokumentation.pdf

Gurak, D. T. / Kritz, M. M. (2000): The Interstate Migration of U.S. Immigrants: Individual and Contextual Determinants, Social Forces 78, 1017-1039.

Haug, S. (2000): Soziales Kapital und Kettenmigration. Italienische Migranten in Deutschland, Opladen

Heckmann, F. (1992): Ethnische Minderheiten, Volk und Nation. Soziologie interethnischer Beziehungen, Stuttgart.

Huinink, J. / Kley, S. (2008): Regionaler Kontext und Migrationsentscheidungen im Lebensverlauf. In: F. Kalter (eds.), Migration und Integration, Wiesbaden, 162-184

Hunt, J. (2006): Staunching emigration from East Germany. Age and the determinants of migration, Journal of European Economic Association 4, 1014-1047.

Jürges, H. (1998): Beruflich bedingte Umzüge von Doppelverdienern - Eine empirische Analyse mit Daten des SOEP, Zeitschrift für Soziologie 27, 358-377.

Jürges, H. (2005): The Geographic Mobility of Dual-Earner Couples: Does Gender Ideology Matter? DIW Berlin Discussion Paper, Nr. 474.

Kalter, F. (1997): Wohnortwechsel in Deutschland - Ein Beitrag zur Migrationstheorie und zur empirischen Anwendung von Rational-Choice-Modellen, Opladen.

Kley, S. (2008): Die Verbundenheit mit dem Wohnort Wegzugsabsichten bei jungen Erwachsenen, $M$. Windzio / F. Hillmann (eds.), Migration und städtischer Raum. Chancen und Risiken der Segregation und Integration, Opladen, 121-136 
Kley, S. (2009): Migration im Lebensverlauf - Der Einfluss von Lebensbedingungen und Lebenslaufereignissen auf den Wohnortwechsel, Wiesbaden.

Kritz, M. M. / Nogle, J. M. (1994): Nativity Concentration and Internal Migration among the Foreign-Born, Demography 31, 509-524.

Kulu, H. / Billari, F. C. (2004): Multilevel Analysis of Internal Migration in a Transitional Country: The Case of Estonia, Regional Studies 38, 679-696.

Kulu, H. / Billari, F. C. (2006): Migration to urban and rural destinations in post-Soviet Estonia: a multilevel event-history analysis, Environment and Planning A 38, 749-764.

Mai, R / Scharein, M. (2009): Effekte der Binnenmigration auf die Bevölkerungsentwicklung und Alterung in den Bundesländern. In: I. Cassens / M. Luy / R. Scholz (eds.), Die Bevölkerung in Ost- und Westdeutschland. Demographische, gesellschaftliche und wirtschaftliche Entwicklung seit der Wende, Wiesbaden.

McGinnis, R. (1968): A Stochastic Model of Social Mobility, American Sociological Review 33, 712-722.

Mertens, A. / Haas, A. (2006): Regionale Arbeitslosigkeit und Arbeitsplatzwechsel in Deutschland. Eine Analyse auf Kreisebene, Jahrbuch für Regionalwissenschaft 26, 147-169.

Mood, C. (2010): Logistic Regression: Why We Cannot Do What We Think We Can Do, and What We Can Do About It, European Sociological Review 26, 67- 82.

Newbold, K. B. (1999): Spatial Distribution and Redistribution of Immigrants in the Metropolitan United States, 1980 and 1990, Economic Geography, 254-271.

Schündeln, M. (2007): Are Immigrants More Mobile Than Natives? Evidence from Germany, IZA Discussion Paper No. 3226.

Sjaastad, L. A. (1962): The Costs and Returns of Human Migration, The Journal of Political Economy 70, 80-93.

Spilimbergo, A. / Úbeda, L. (2004): Family attachment and the decision to move by race, Journal of Urban Economics 55, 478-497.

Statistisches Bundesamt (2009): Bevölkerung mit Migrationshintergrund - Ergebnisse des Mikrozensus 2007, Fachserie 1 Reihe 2.2, Wiesbaden.

Vidal Torre, S. / Kley, S. (2010): The Geographic proximity of Social Ties in Migration Intentions and Behaviour. MIGREMUS WP, Nr.1/2010.

Vidal Torre, S. (2009): Does the extended family cause migration?, Essays on residential trajectories and social ties in the stage of early adulthood. Universitat Pompeu Fabra, 43-92.

Wagner, M. (1989): Räumliche Mobilität im Lebensverlauf - Eine empirische Untersuchung sozialer Bedingungen der Migration, Stuttgart.

Wagner, G. G. / Frick, J. R. / Schupp, J. (2007): The German Socio-Economic Panel Study (SOEP): Scope, Evolution and Enhancements, Schmollers Jahrbuch 127, 139-169

Windzio, M. (2004a): Kann der regionale Kontext zur „Arbeitslosenfalle“ werden? Der Einfluss der Arbeitslosigkeit auf die Mobilität zwischen regionalen Arbeitsmärkten in Westdeutschland, Kölner Zeitschrift für Soziologie und Sozialpsychologie 56, 257-278.

Windzio, M. (2004b): Zwischen Nord- und Süddeutschland: Die Überwindung räumlicher Distanzen bei der Arbeitsmarktmobilität, Zeitschrift für Arbeitsmarktforschung 1, 29-44. 


\section{Appendix}

Table A1

Characteristics of the variables used in the analysis

\begin{tabular}{|c|c|c|c|c|c|}
\hline Variables & $\mathbf{N}$ & Mean & Std. Dev. & Min & Max \\
\hline \multicolumn{6}{|l|}{ Dependend variable } \\
\hline internal migration & 44952 & 0.01 & 0.11 & 0 & 1 \\
\hline \multicolumn{6}{|l|}{ Independent variables } \\
\hline \multicolumn{6}{|c|}{ Individual and household characteristics } \\
\hline native born German & 44952 & 0.88 & 0.33 & 0 & 1 \\
\hline immigrant, 1st gen. & 44952 & 0.09 & 0.28 & 0 & 1 \\
\hline immigrant, 2nd gen. & 44952 & 0.03 & 0.18 & 0 & 1 \\
\hline age & 44952 & 43.18 & 10.64 & 16 & 65 \\
\hline $\operatorname{sex}($ female=1) & 44952 & 0.37 & 0.48 & 0 & 1 \\
\hline married & 44952 & 0.60 & 0.49 & 0 & 1 \\
\hline children in hh & 44952 & 0.40 & 0.49 & 0 & 1 \\
\hline \multicolumn{6}{|l|}{ Education level } \\
\hline without adequate degree & 44952 & 0.01 & 0.12 & 0 & 1 \\
\hline general/basic vocational & 44952 & 0.36 & 0.48 & 0 & 1 \\
\hline intermediate & 44952 & 0.27 & 0.44 & 0 & 1 \\
\hline maturity certificate & 44952 & 0.12 & 0.33 & 0 & 1 \\
\hline tertiary education & 44952 & 0.23 & 0.43 & 0 & 1 \\
\hline \multicolumn{6}{|l|}{ Employment status } \\
\hline in education & 44952 & 0.02 & 0.13 & 0 & 1 \\
\hline unemployed & 44952 & 0.06 & 0.24 & 0 & 1 \\
\hline not working & 44952 & 0.04 & 0.20 & 0 & 1 \\
\hline self employed & 44952 & 0.11 & 0.31 & 0 & 1 \\
\hline employed & 44952 & 0.77 & 0.42 & 0 & 1 \\
\hline \multicolumn{6}{|l|}{ Regional embeddedness } \\
\hline occupancy (In) & 44952 & 2.02 & 0.92 & 0 & 4.61 \\
\hline homeownership & 44952 & 0.47 & 0.50 & 0 & 1 \\
\hline \multicolumn{6}{|l|}{ County level determinants } \\
\hline unemployment rate $^{1}$ & 44952 & 0 & 3.67 & -7.53 & 16.16 \\
\hline nativity concentration $^{2}$ & 44952 & 0.11 & 1.04 & -3.17 & 9.37 \\
\hline \multicolumn{6}{|l|}{ District classification } \\
\hline nuclear town & 44952 & 0.31 & 0.46 & 0 & 1 \\
\hline urban hinterland & 44952 & 0.50 & 0.50 & 0 & 1 \\
\hline rural hinterland & 44952 & 0.09 & 0.29 & 0 & 1 \\
\hline rural area & 44952 & 0.10 & 0.29 & 0 & 1 \\
\hline
\end{tabular}

${ }^{1}$ county level unemployment level is grand mean centered.

${ }^{2}$ nativity concentration refers respectively to the concentration of guest worker origin population or to the concentration of Germans in one county, the variable is z-transformed.

Source: Own calculations, GSOEP 2000-2009 
Table A2

Documentation of the variables used in the analysis.

\begin{tabular}{|c|c|c|}
\hline Variables & GSOEP originial variables & Based on wave \\
\hline \multicolumn{3}{|l|}{ Dependend variable } \\
\hline internal migration & $\begin{array}{l}\text { moveyr\$, qh01, rh01, sh01, th01, uh01, vh01, } \\
\text { wh01, xh01, yh01, zh01, chg_kkz, distance, } \\
\text { ?hhnr }\end{array}$ & $2000-2009$ \\
\hline \multicolumn{3}{|l|}{ Independent variables } \\
\hline $\begin{array}{l}\text { Migration background: } \\
\text { native born German } \\
\text { immigrant, 1st gen. } \\
\text { immigrant, 2nd gen. }\end{array}$ & $\begin{array}{l}\text { vnat, mnat, astell, estell, nation\$\$, ?pnat, immi- } \\
\text { year, germborn, corigin, migback, gebjahr, } \\
\text { ak07a, ek03a, ap62a, bp98a, cp98ab, dp95a, } \\
\text { ep88a, fp105a, gp105a, hp105a, ip105a, jp105a, } \\
\text { qp12002, rp11602, sp11503, tp12302, up12702, } \\
\text { vp13602, wp12802, xp14002, yp13802, } \\
\text { zp13802, sp11702, qp12102, rp11702, wj6201, } \\
\text { xj62, yj62, zj62. }\end{array}$ & $1984-2009$ \\
\hline age & gebjahr & 2009 \\
\hline sex (female=1) & Sex & 2009 \\
\hline married & ?famstd & 2000-2008 \\
\hline children in hh & ?kzahl & $2000-2008$ \\
\hline $\begin{array}{l}\text { Education level } \\
\text { without adequate degree } \\
\text { general/basic vocational } \\
\text { intermediate } \\
\text { maturity certificate } \\
\text { tertiary education }\end{array}$ & $\begin{array}{l}\text { casmin } \$ \$ \\
\text { if } \operatorname{casmin} \$ \$==0 \mid \text { casmin } \$ \$==1 \\
\text { if } \operatorname{casmin} \$ \$==2 \mid \operatorname{casmin} \$ \$==3 \\
\text { if } \operatorname{casmin} \$ \$==4 \mid \operatorname{casmin} \$ \$==5 \\
\text { if } \operatorname{casmin} \$ \$==6 \mid \operatorname{casmin} \$ \$==7 \\
\text { if } \operatorname{casmin} \$ \$==8 \mid \operatorname{casmin} \$ \$==9\end{array}$ & $2000-2008$ \\
\hline $\begin{array}{l}\text { Employment status } \\
\text { in education } \\
\text { unemployed } \\
\text { not working } \\
\text { self employed } \\
\text { employed }\end{array}$ & $\begin{array}{l}\text { casmin\$\$, stib\$\$, Ifs\$\$ } \\
\text { if stib\$\$==11 | casmin\$\$==0 } \\
\text { if stib\$\$==12 } \\
\text { if stib\$\$==10 } \\
\text { if stib\$\$==410|==440 } \\
\text { nonmis, except stib\$\$==5 | ==6 } \\
\text { Ifs\$\$==4 \& Ifs\$\$!=5 }\end{array}$ & $2000-2008$ \\
\hline $\begin{array}{l}\text { Regional embeddedness } \\
\text { occupancy (In) } \\
\text { homeownership }\end{array}$ & $\begin{array}{l}\text { moveyr\$\$ } \\
\text { owner\$\$ }\end{array}$ & $\begin{array}{l}2000-2008 \\
2000-2008 \\
\end{array}$ \\
\hline unemployment rate & \$alq & $2000-2008$ \\
\hline nativity concentration & \$bev_g and external data & $2000-2008$ \\
\hline $\begin{array}{l}\text { District classification } \\
\text { nuclear town } \\
\text { urban hinterland } \\
\text { rural hinterland } \\
\text { rural area }\end{array}$ & External data from INKAR 2008 & 2008 \\
\hline
\end{tabular}

$\$ \$$ refers to the last digits of the years from 2000 to $2008 / 2009$.

? refers to the waves Q (2000) to Y (2008) or Z (2009).

Source: GSOEP 1984-2009, INKAR 2008 and Federal Statistic Offices 